\title{
Ensuring sustainable imports of soybeans to China: a comparative study of bilateral foreign trade with Brazil
}

\author{
Natalia Yevchenko ${ }^{1,}$, Lincong Li, and Zhidong Huang ${ }^{1}$ \\ ${ }^{1}$ The Sothern Federal University, 105/42 Bolshaya Sadovaya str., 344006 Rostov-on-Don, Russia
}

\begin{abstract}
The article discusses the problem of sustainable soybean imports to China as a strategic food product. Extensive and intensive factors, determine the soybean supply to China was identified. It has been established that the China-Brazil soybean foreign trade is characterized by a constant increase in bilateral interdependence, characterized by volumes and prices. It was revealed that the prices of soybeans in the Brazilian market are formed by China's demand and are the lowest of imported into China. It has been proven an increase in the soybean imports volatility in China: the monopoly strengthening of the key supplier (Brazil) and the rise of purchase prices, the inclusion of China's political commitments in foreign soybean trade with the United States. It has been established that the extensive factors on the soybean imports increasing are near to be exhausted. It is suggested that China will be enforced to use intensive factors of soybean imports sustainability: diversification of soybean import sources, including initiation of public-private partnership contracts, policy adjustments to deepen ChinaBrazil-USA-Russia soybean trade cooperation, exploring investments in neighboring countries. A plan for expanding educational and scientific cooperation with Russia is presented, aimed at expanding production and soybean foreign trade with the PRC.
\end{abstract}

\section{Introduction}

China, with a huge agricultural trade volume, has become the world's largest importer of agricultural products and the second-largest agricultural trade country. Soybean is the largest agricultural product in China, more than $80 \%$ of which is used as protein feed. According to the Ministry of Agriculture and Rural Affairs, China imported 88,5 million tons of soybeans in 2019 , accounting for about $85 \%$ of domestic consumption and about $60 \%$ of global soybean imports.

Soybean is a land-intensive crop, which is beneficial to alleviate the shortage of land resources in China. At present, domestic demand and production costs are relatively high, according to the theory of comparative advantage, through imports to meet domestic soybean demand. It is not only the necessity of agricultural development but also the necessity of

\footnotetext{
*Corresponding author: natayevch@yandex.ru
} 
rational choice [1]. In 2019, China's soybean self-sufficiency rate was only about $13 \%$, a record low [2]. Soybean has become the key to ensure China's food security.

Therefore, China urgently needs to find new trading partners such as Brazil, Argentina, and Russia to ensure the security of the soybean import value. In terms of output, Brazil is the world's largest soybean producer-only second to the United States and China's largest soybean import trading partner. China and Brazil are members of the BRICS countries and have maintained good bilateral relations for a long time, which has established a stable political basis for cooperation between the two sides in soybean import and export trade.

As for China's soybean dilemma, it mainly results from two factors: production and trade. The researchers specified the influencing factors of soybean production from the following aspects.

First, the influence of soybean policy on soybean production. $\mathrm{Xu}, \mathrm{H}$. et al. [3] believe that the factors that affect soybean production in China under the condition of the open market are: soybean import volume increases or decreases, and foreign capital is higher than any other period in history. The impact on the small and medium-sized enterprises with soybean as the main business greatly reduced the planting intention of soybean farmers and increased the uncertainty of the soybean market. Wei, J. et al. [4] analyzed the influence of soybean price on soybean production in China. It is believed that soybean prices in China are in a passive position in the international market, which makes soybean farmers in China have a low willingness to plant soybeans.

Second, the influence of soybean supply and demand on soybean production. Wei, P. analyzed the influence of market supply and demand on domestic soybean production, and held that the stagnation of domestic soybean supply and the excessively rapid growth of imported soybeans were the main factors resulting in the Chinese soybean dilemma [5]. Guo, $\mathrm{X}$. et al. analyzed the influence of the soybean processing industry on its production in China [6].

Third, the influence of the soybean planting environment on soybean production. Wang, L. et al. [7] demonstrated the effect of new medicament on domestic yield and concluded that the new medicament Gramin had a good effect on soybean production. Zhang, C. et al. [8] found out the effect of efficient use of organic fertilizer on increasing soybean yield and concluded that the use of organic fertilizer could improve soybean yield and quality. Cheng, M. et al. [9] analyzed the influencing factors of agricultural mechanization on soybean yield and recognized For agricultural mechanization, grain production can be increased in the long run, and grain production can also be increased in the short term.

Fourth, studies on the enhancement of the international competitiveness of soybean. Kong, W. [10] suggested improving the pricing power of the soybean international market in China from the aspects of perfecting the soybean market system, breaking the monopoly of transnational grain traders, supporting the domestic soybean industry, improving the service of government and trade associations, and adjusting the international trade policy. Sun, Y. et al. [11] hold that China should further improve the differentiation level between domestic soybean and imported soybean, strengthen the marking management of transgenic soybean products, and enhance the international competitiveness of soybean.

With the rapid development of the economy and the improvement of people's living standards, China's demand for soybeans has shown explosive growth, which is difficult to meet the market demand by domestic production alone, and the gap is increasing. In response to this situation, the focus on soybeans has shifted more to international trade. Wei, H. [12] analyzed the advantages and disadvantages of the soybean trade war from the national level and predicted the future trade situation. Wang, L. [13] introduced the influence of China-US trade friction on China's soybean industry and put forward countermeasures. Ma, S. [14] used the Spearman Index to analyze the import volume of soybean China, the export volume of the United States, the world import volume, and the world export volume. It is found that the 
import quantity of Chinese soybean has a strong correlation with the international soybean market price.

Liu, J. [15] adopted the gravity model to predict the effect of Sino-US trade friction on soybean production in China and put forward suggestions for China's anti-US soybean imports. Guo, T. [16] analyzed the influencing factors of planting area, planting cost, labor culture degree, and mechanization degree, and put forward some suggestions to improve soybean yield and productivity. Some scholars (Wang, Han, \& Lu [17]; Zhou \& Qian [18]) compared the costs of Chinese, Brazilian and American Brazilian soybeans respectively and conducted an assessment on the disadvantages of Chinese soybeans.

From the previous studies, scholars mainly concentrated more on the macro level and analyzed the cost of soybean in the United States. Researches on other trade partners are far from enough. A few scholars' research on Brazilian soybean mainly stays at the data level. Compared with the difference in soybean yield and production cost between China and Brazil, the reasons for this difference is not deeply analyzed, and the effective ways of trade cooperation between the two sides not discussed. Under the circumstance of China-US trade policy circumstances, the potential of China to import Brazilian soybean is especially obvious.

To highlight the vital and rising importance of the soybean supply in-country food balance, this paper analyzes the current situation and influencing factors of sustainable soybean imports to China.

Based on the foreign trade trends for products (soybean) between China and Brazil, there is a need to put forward concrete measures to analyze the improvement China's soybean import supply.

\section{Materials and method}

Based on the monographic survey, the first part of the paper reviews the scientific literature on the issues related to the problems of studying the strategic importance of soybeans in the PRC's food balance, the current state of soybean production in China and the world, the foreign trade of key states of soybeans suppliers and buyers. The results of the previous studies are discussed.

Based on empirical statistics from FAO, UNCTAD, and the World Bank, the second part of the paper reveals the dynamics, price parameters, structure, foreign trade value, forecast conditions, and key potential opportunities for ensuring sustainable soybean imports to China. Attention is focused on bilateral foreign trade in soybeans of Brazil (supplier) and China (buyer).

In the concluding section, the results of the study and the main inferences are formulated.

The research methods are grouping, analytic calculations, and graphics.

The data on the volumes of exports and imports are presented in current prices in US dollars (billions \$ US). The physical volumes of soybean supplies are given in tons (millions of tons).

The research period is 2001-2020.

The purpose of the research - based on the analysis of bilateral soybeans foreign trade of two largest in the world partners - supplier (Brazil) and buyer (China) - to reveal the dynamics of foreign trade, price parameters, economic efficiency, the potential trends for further development of mutual trade and to formulate provide directions sustainability of soybean imports in China in the medium term.

The hypothesis of the research is based on the assumption that the sustainability of China's soybean imports to as a food security product of the state is influenced by a significant number of factors, including both traditional production and growing in 
importance price and trade-political factors; and assumes a multivariate diversification of imports to lower soybean prices compared to Brazilian shipments

\section{Results and Discussion}

\subsection{Composition of soybean trade between China and Brazil, and partner countries}

China's total soybean import value grew from 2001 to 2019. Fig. 1 indicates that China's soybean imports increased slightly from 2001 to 2007. Affected by the financial crisis, China's soybean imports fell to $\$ 18,8$ billion in 2009 , a decline of $13,9 \%$. Soybean imports fell in 2015 and 2016, with heavy imports in 2017, new growth to $\$ 39,6$ billion. After 2017, the imports dropped slightly to $\$ 35,4$ billion in 2019 .

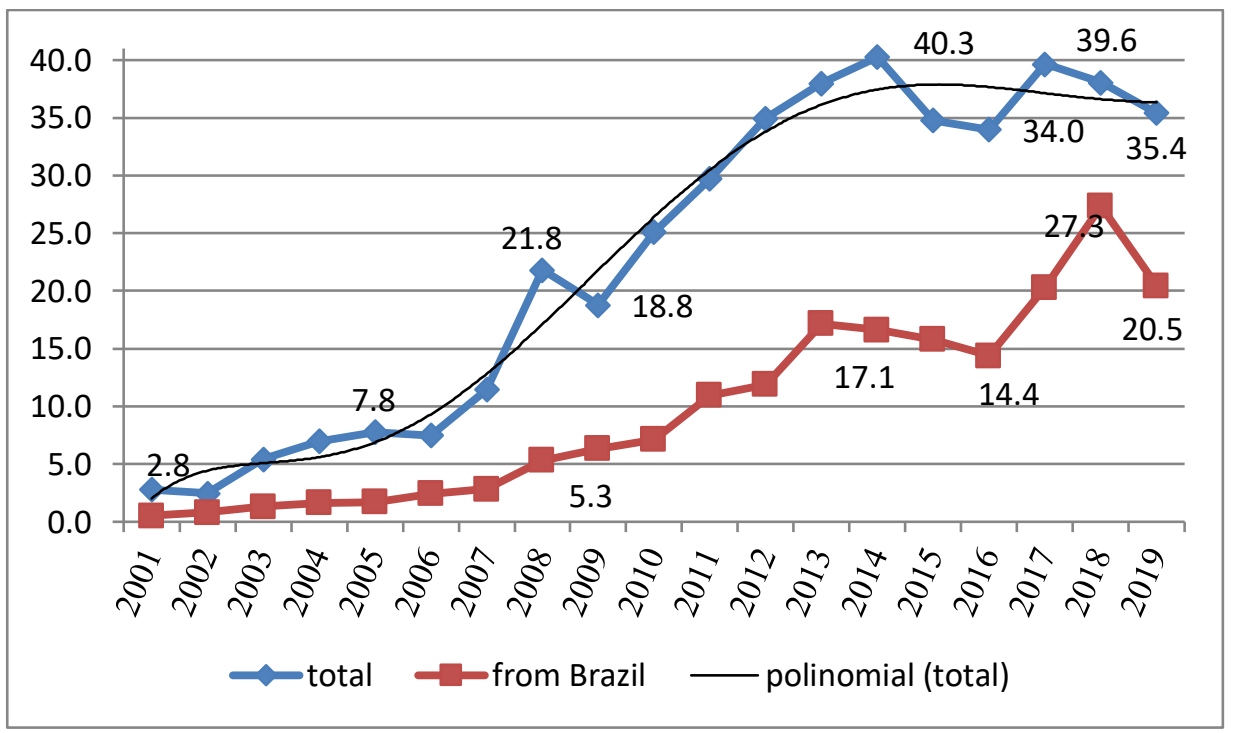

Fig. 1. China's soybean imports: total and from Brazil, 2001-2019, US\$, billions. Source: https:// FAO.org

Country (or regional) composition of Chinese soybean imports: in 2019 China imported soybeans mainly from five countries (FAO data), followed by Brazil, the United States, Argentina, Uruguay and Canada. Among the five countries, Brazil accounted for the largest share of imports, reaching 45,8 \%; the United States accounted for 40,5\%, ranking second; and Argentina ranked third. Brazil and the United States accounted for $86,3 \%$ of imports in all five countries, largely monopolizing China's soybean consumption market field.

In 2019, China's soybean imports reached 88,5 million tons, rising by $0,6 \%, 57,7 \%$ were imported from Brazil, accounting for $65 \%$ of China's soybean imports; 16,9 million tons of soybeans were imported from the United States, representing 19\%; 8,8 million tons were shipped from Argentina, making up $10 \%$; from Canada and Uruguay were imported 2.3 million tons and 2.1 million tons, about $3 \%$ and $2 \%$ respectively; and 0,7 million tons were delivered from Russia (1\%). In 2020, China imported 100,33 million tons of soybeans, including shipments from Brazil of 64,28 million tons and from the United States 25,89 million tons, or $90,2 \%$ of total import. 
From the perspective of import volume and trend, China's share of imports from Brazil is increasing, and continuing to maintain and stabilize the soybean trade between China and Brazil will be China's key strategy for a long time to come.

The data presented in Fig. 1 can be approximated as a result of polynomial regression analysis according to equation (1):

$$
\mathrm{Y}=-0,000027 * \mathrm{x}^{6}+0,0021 * \mathrm{x}^{5}-0,0581 * \mathrm{x}^{4}+0,7271 * \mathrm{x}^{3}-3,9754 * \mathrm{x}^{2}+10,065 * \mathrm{x}-4,7479
$$

where Y - China's soybean imports (model value, dependent variable); $\mathrm{X}$ - point serial number.

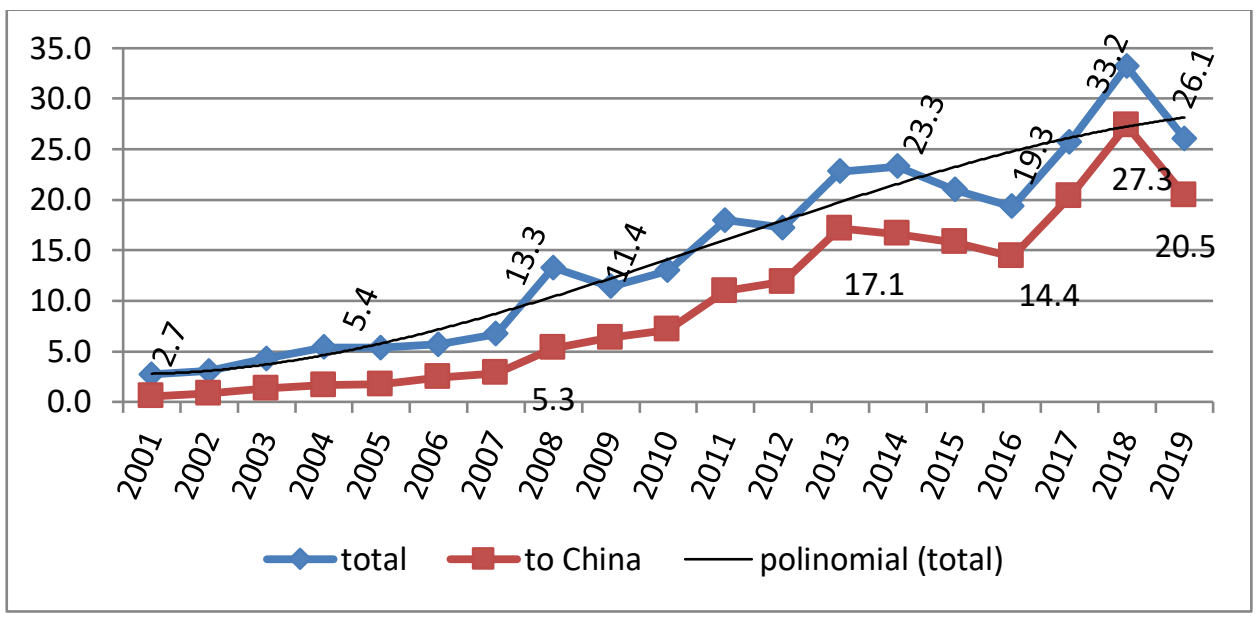

Fig. 2. Brazil's soybean exports: total and to China, 2001-2019, US\$, billions. Source: https:// FAO.org

With the rise of Brazil's economy in the 1980s, relying on the unique geographical advantages of producing soybeans in the subtropical region, coupled with the relative abundance of labor factors, Brazil's export of soybeans soared beyond the US and Argentina.

Brazil's overall soybean exports were relatively large between 2001 and 2019 (Fig. 2). Exports amounted to $\$ 2,7$ billion in 2001 and $\$ 26,1$ billion in 2019, an increase of about nine folds over the 18 years. In terms of the growth rate of Brazilian soybean exports, the growth rate fluctuated relatively frequently. During the financial crisis, Brazil's soybean export trade was also affected by economic fluctuations. Both in 2009 and 2010 there was a slight decline. Along with the recovery of the world economy, soybean exports increased slightly from 2011 to 2014 , with moderate growth of about $22,1 \%$, and peaked in 2018 , exceeding $\$ 33,2$ billion.

Brazilian soybeans are mainly exported to China. In 2019, Brazil exported \$20,5 billion of soybeans to China (78,4\% of Brazilian total soybean export). Brazilian exports to Spain amounted to $\$ 598,7$ million to the west and to Thailand to $\$ 586,6$ million, accounting for 3,1 $\%$ and 3,0 \%, respectively. Other trading partners for Brazil's exports include the Netherlands, Iran, Russia, Taiwan and Germany.

The data presented in fig. 2 can be approximated as a result of polynomial regression analysis according to equation (2):

$$
\mathrm{Y}=-0,006 * \mathrm{x}^{3}+0,1975^{*} \mathrm{x}^{2}-0,2445 * \mathrm{x}+2,8275
$$

where Y - Brazil's soybean exports (model value, dependent variable);

$\mathrm{X}$ - point serial number. 


\subsection{Soybeans price as a factor of bilateral China-Brazil trade}

According to the FAO data, domestic soybeans do not have price advantages over imported soybeans. For example, in 2015, the cost of soybean production in the United States was $\$ 329,0$ per ton, in Brazil - $\$ 317,1$, in China - \$581,5, and the global (world) average level was $\$ 400,2$. China's soybean cost was about $\$ 260,0$ per ton higher than the United States and Brazil, which made domestic soybeans less competitive in price. Considering the above factors, it can be predicted that China's soybean import in next few years will still remain a strong momentum and soybean security will be the key factor for Chinese food security.

The scientific task of the study to find factors for ensuring the sustainability of soybean imports by China revealed the features of price strategies in the regional areas of exports (Brazil) and imports (China), presented in Fig. 3 and Fig. 4.

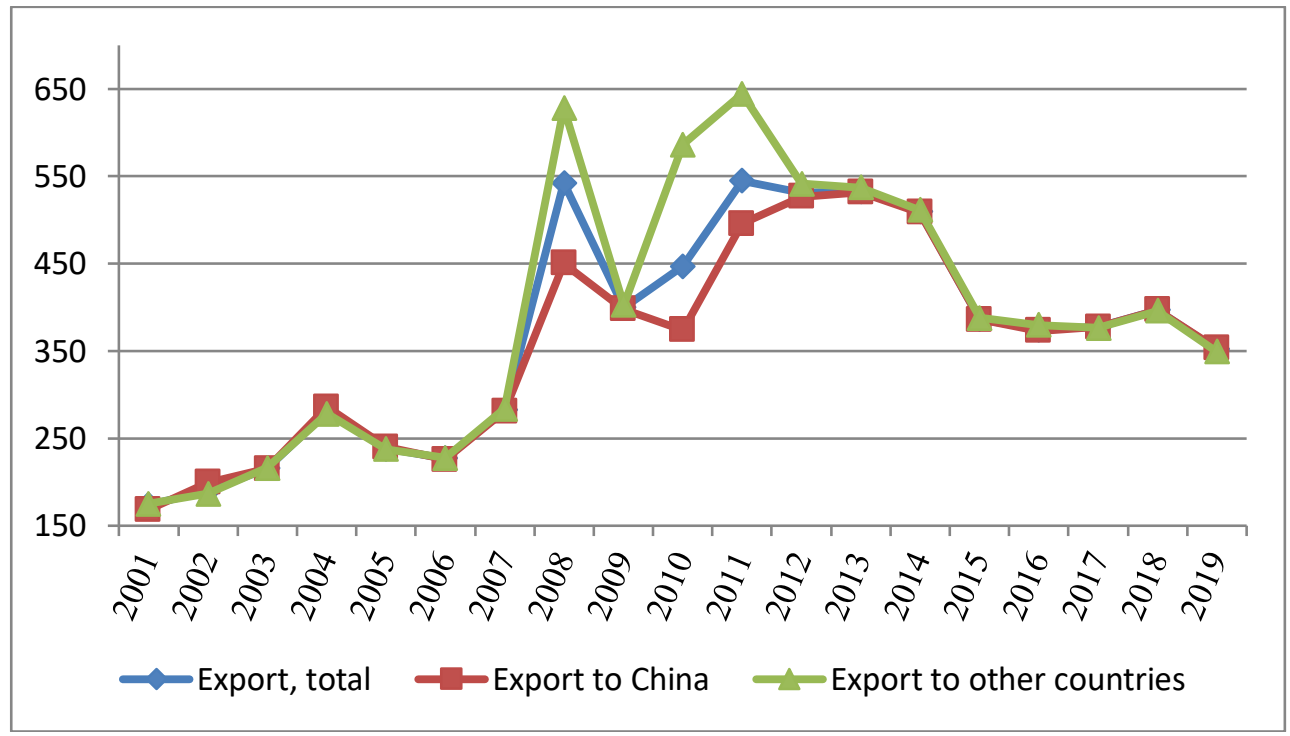

Fig. 3. Brazil's soybean exports average price: total, to China, to other buyers, 2001-2019, US\$/ ton Source: https:// FAO.org

Calculations for the establishment of the average export price per $t$ of soybeans show that for the Brazilian market was formed completely by the China's pricing policy towards trade. Some volatility in price growth during the 2008-2011 crises indicates that during this period Brazil was able to sell some of the soybeans to other countries at a higher price (Fig. 3).

According to statistics, the competitive world price of products with high quality is a key factor in the growth of interdependence in the supply of Brazil's soybean in China.

A similar result for China: during 2001-2019 the price of soybeans from Brazil was the lowest in comparison with all other suppliers, with the difference being 50-100 US \$/ton (Fig. 4). This dependency was not disrupted throughout the data analysis period.

Thus, the sustainability of imports of soybeans to China in the future is associated, first of all, with the ability of all possible potential soybean producers in the world to provide a price close to the price of production and export of Brazil. However, it should be noted that this statement requires more detailed consideration when taking into account the genetic modification of soybeans and its share in China's imports. 


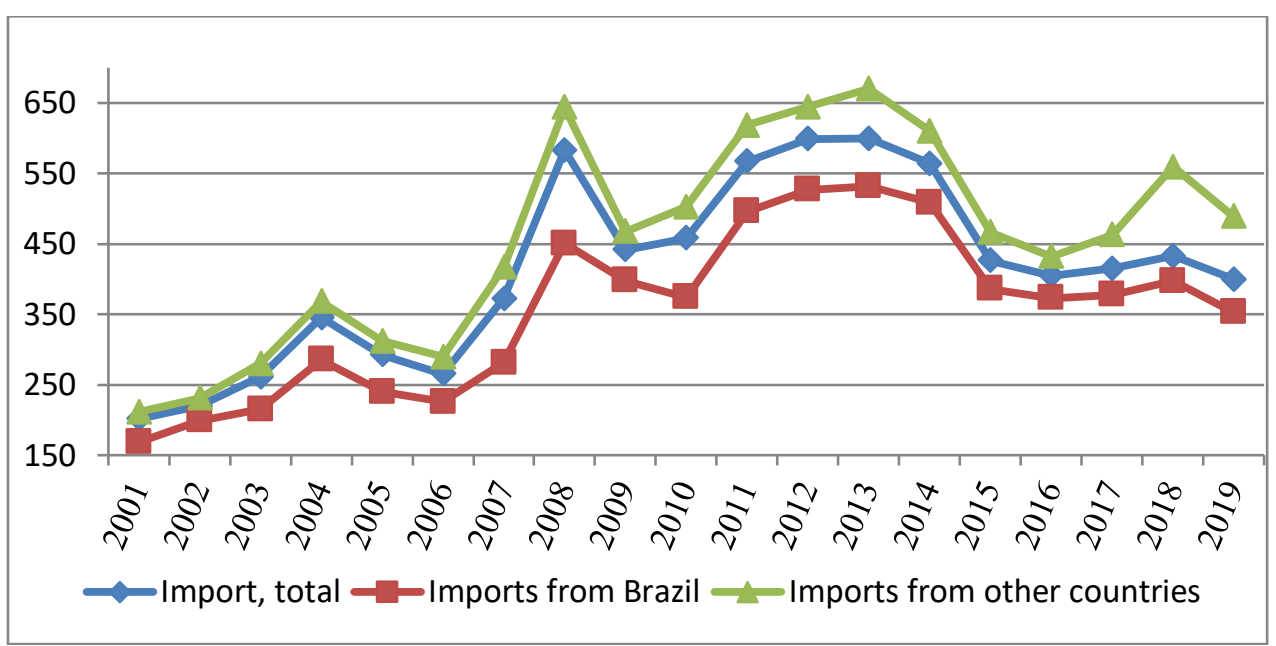

Fig. 4. China's soybean imports average price: total, from Brazil, from other suppliers, 2001-2019, US\$/ton Source: https:// FAO.org

\subsection{Multivariate diversification of suppliers as an intensive factor in ensuring the sustainability of soybean imports to China}

The proteins and lecithin in soybeans have health effects on the human body, and Chinese pay more attention to green and healthy quality of life. Therefore, the increase of soybean demand is more and more obvious. China and Japan have similar nutritional intake. However, according to FAO statistics, the average annual soybean intake in Japan from 1961 to 2013 is significantly higher than that in China, such as $3,87 \mathrm{~kg} /$ year per capita soybean consumption in 2013 and 7,34 kg/year in Japan, which indicates that China's per capita soybean consumption still has a lot of room for growth, and the limited domestic soybean supply will not be able to meet the rapidly growing soybean demand [19].

To reduce the risk of China's soybean market and solve the situation that demand exceeds supply, it is far from possible to increase domestic output alone. Han Jun, deputy minister of agriculture and rural areas of the PRC, said that considering the reasons of resource endowment, the situation of China's soybean mainly relying on foreign markets will not change.

\subsubsection{Strengthening China-Brazil-USA soybean trade cooperation}

The China-USA trade war caused damage to both sides--higher tariffs and lower quotas have added to the burden on consumers in both countries. In this case, in order to ease the situation and realize their economic interests, China and the United States signed a trade agreement on January 15, 2020. The agreement provides for agricultural goods: “...no less than $\$ 12,5$ billion above the corresponding 2017 baseline amount is purchased and imported into China from the United States in calendar year 2020, and no less than $\$ 19,5$ billion above the corresponding 2017 baseline amount is purchased and imported into China from the United States in calendar year $2021 \ldots$ The Parties project that the trajectory of increases in the amounts of manufactured goods, agricultural goods, energy products, and services purchased and imported into China from the United States will continue in calendar years 2022 through 2025." The signing of this agreement has had an immediate effect. According to China's General Administration of Customs, China's imports of USA soybeans rebounded to a record $\$ 14,2$ billion in 2020 , an annual increase of $77,8 \%$. 
Brazilian soybeans contain 38\% protein and fewer impurities, while American soybean protein content is only about $34,1 \%$. Furthermore, the South American soybean transport board will be improved. The BR-163 road connecting the Brazilian soybean production area and the Amazon River has been completed since 2019, with a shorter transportation distance of $500 \mathrm{~km}$, therefore, Brazilian soybeans will be more competitive than Americans. It is worth mentioning that since 2012, the market share of U.S. beans in China has been squeezed by South American soybeans such as Brazil, with China importing 65,2\% of Brazilian soybeans in 2019 and from the United States only 19,1\%. In the current stable bilateral relations between China and Brazil, the governments should play a leading role, strengthen international exchanges and interaction, and form a joint force for development. In key foreign-related agricultural cooperation and development projects, China-Brazil policy should help decision-making level linkage, jointly issued preferential policies and support measures to ensure the precise docking of bilateral policies and measures, its effective implementation. Two countries should establish and improve the mechanism of regular communication and consultation between the countries, to actively avoid the bottleneck restricting development due to bilateral information asymmetry, and to jointly negotiate and efficiently solve practical problems in bilateral trade. It could be useful to be more familiar with the political, economic, human, and social environment of Brazil, and develop professional knowledge, and form a team of business professionals.

\subsubsection{Exploring multilateral cooperation, investments and education with neighboring countries: Russia \& Fare-East case}

In the process of actively participating in the international food trade, it is necessary to deepen trade exchanges with grain exporting countries and, at the same time, industry-wide cooperation with grain trading countries, which can not only stabilize trade partnerships and reduce trade resistance but also complement each other through in-depth cooperation and gain mutual benefit. In order to achieve the purpose of ensuring national food security, it is advisable to selectively increase regional food trade cooperation, especially in regional food security, enhance the construction of free trade zones, remove trade barriers, and actively promote the facilitation of food trade.

In the field of soybean, it is very important for a large agricultural country like China to seek long-term stable trading partners, reduce the risk of soybean import, and ensure food security. Since the outbreak of the Sino-US trade war, China's imports of soybeans from the United States have plummeted, while imports from Brazil and Argentina have soared. In fact, the quality and price of soybeans from the United States are lower. The current situation put forward a new China's soybean trade policy in imports: there is a need for stable bilateral relations, quality, and price.

According to the theory of trade gravity, China and Russia are geographically bordered and the bilateral trade costs are low. China's import of soybeans from Russia is an ideal choice. In addition, China and Russia have long maintained good political relations, which have laid a solid foundation for the two sides to keep the momentum of trade growth for a long time, conducive to China's efforts to stabilize soybean imports and ensure food security. For this, the method of expanding investment in branch-project corridors can be used by using the principles of public-private partnerships and state orders [20], as well as the optimal conditions and principles for enhancing interregional financial and investment cooperation [21].

Since 2018, Russia has promised to increase land supply and preferential financing for projects involving Chinese investors in its agricultural development plan. The Russian Far East agricultural sector is willing to provide 1 million hectares of land to Chinese enterprises for new agricultural investment projects [22]. It is expected that Chinese agricultural enterprises invest in product processing and soybean planting. The Russian Far East has a 
large area of agricultural land available, which is worthy of agricultural investment. In addition, the land rent and the production cost are rather low; the black soil and the high organic content are beneficial to mechanized planting, which has great agricultural investment value. More importantly, non-GM soybeans are grown in Russia, in line with the government's policy requirements for edible soybeans, and there are no threshold restrictions on exports to China.

Since 2003, China and Russia have intensified cooperation and signed a series of agricultural technology cooperation agreements, including developing organic agriculture, promoting cooperation and exchanges in breeding technology, pest control technology, and genetic gene preservation. Chinese Heihe City, as the pioneer of Sino Russian agricultural science and technology cooperation, has established a long-term and stable cooperative relationship with the Russian Academy of Agricultural Sciences and Far East Agricultural University of Russia for many years. In 2009, Heihe City officially established a demonstration park of agricultural high-tech cooperation between China and Russia, where technical experts are from the Chinese Northeast Agricultural University and Russian Khabarovsk State Pedagogical University cooperated. Heilongjiang Province gives full play to its local advantages, the agricultural cooperation with Russia is gradually expanding. In 2018, the area of bilateral agricultural cooperation has expanded to six states of Russian Far East area, including Primorsky kray and Amurskaya oblast, and four cooperative agricultural parks have been built in Primorsky kray [23].

In recent years, with Baicheng Academy of Agricultural Sciences in Jilin Province as the cooperation platform, it has carried out cooperation with the Russian Academy of Agricultural Sciences in the fields of breeding, cultivation, and processing technology of oat, winter rye, buckwheat, potato, pea and other crops, which has achieved satisfactory cooperation results between China and Russia. The Russian Academy of Sciences, the Samara Institute of Agricultural Research, the Northeast Branch of the Russian Academy of Sciences, and the Russian Institute of Cereal and Legume Crops Research have taken part in agricultural research cooperation. Through the establishment of joint laboratories, they can give full play to their advantages, and new achievements will benefit the agriculture of both countries [24].

In 2017, Chinese Northwest Agriculture and Forestry University and Russian Omsk State Agricultural University jointly launched and established Sino Russian Agricultural Education Cooperation and Science-Technology Innovation Alliance. The Alliance includes 16 institutions: Beijing Forestry University, Shandong Agricultural University, Nanjing Agricultural University, Central China Agricultural University, Henan Agricultural University, Chinese Academy of Agricultural Sciences, Xinjiang Academy of Agricultural Sciences, Northwest Agriculture and Forestry University. And Russian universities are Moscow State University of Environmental Engineering, Primorsk State Agricultural Academy, South Ural State University, Omsk State Agrarian University, Oryol State University, Krasnoyarsk State Agrarian University, Ural State Agricultural Academy, and Yakutsk State University.

Under the framework of agricultural education cooperation, the alliance aims to promote mutual cooperation and benefit. It is committed to promoting the close cooperation between agricultural universities and scientific research institutions of China and Russia in personnel training, scientific research, technology promotion, people-to-people exchanges, policy research, etc., so as to promote the economic and social development of China and Russia.

Therefore, it is feasible to strengthen regional cooperation in agricultural education, for example, to set up joint education bases in developed agricultural areas in Heilongjiang Province of China or Far East of Russia. Chinese Heihe City has already established a deep processing base of Russian imported organic soybean which is significant to improve 
preferential conditions for agricultural education and promote bilateral education cooperation in agriculture.

There is a high potential $\mathrm{n}$ strengthening the training of high-level personnel. For Russian universities, it is an opportunity to exploit China's higher education market with advantageous agricultural disciplines and strengthen agricultural education cooperation by combining the curriculum with the needs of China's agricultural development.

\section{Conclusion}

By analyzing and comparing the current situation of the soybean industry and trade cooperation between China and Brazil, this paper finds out the difficulties faced by China's soybean market and explores the corresponding solutions. Specifically, there is a need in deepening multi- and bilateral trade cooperation. However, it is even more important to seek multilateral cooperation to develop multiple trading partners and lower soybean risks. Therefore, while conducting trade negotiations with the United States to try to stabilize soybean imports and strive for more benefits, strengthening soybean trade with Argentina, Canada and Uruguay will assist China to reduce the risk of excessive soybean dependence from Brazil.

The research showed that since the early 2000s, the consumption of soybeans in China has grown exponentially, which was satisfied by highly competitive production in Brazil. The interdependence of soybean supplies for Brazil to China has reached a critical size about $80 \%$ of Brazil's soybean exports and about $2 / 3$ China's imports.

It is obvious that the medium-term forecast for growth in consumption in China can no longer be met by an extensive increase in soybean imports from Brazil. It is necessary to develop a systemic plan for the growth of intensive factors of production and imports of soybeans. Among the key activities, both traditional internal factors (industry subsidies, investment in soybean science and technology innovation) and relatively new external factors (strengthening China-Brazil-USA soybean trade cooperation, multilateral and bilateral cooperation and investments activity with neighboring countries) can be considered.

It seems also promising to expand scientific and educational cooperation with China in agricultural production, including the regions of both states. The forms of such cooperation can become and continue to carry out joint research, training of professional personnel, students' and professors' educational and research exchange programs.

\section{References}

1. Research Group of the Agricultural Trade Promotion Center of the Ministry of Agriculture. From comparative advantage, why does China import soybeans. Nongcun Baishitong 11, 19-20 (2019)

2. J. Wang, Y. Han, H. Lu, The Comparative Study on Soybean Trade in China and Brazil. Modern Management Science 11, 15-17 (2018)

3. H. Xu, W. Liu, China soybean industry development crisis and warning. Forum of Chinese Party and Government Cadres 10, 37-39 (2012)

4. J. Wei, L. Zhang, T. Hu, Empirical Analysis on the Influence Factors of Soybean' Production Price Fluctuation. Journal of Sichuan Agricultural University 35(3), 445-451 (2017)

5. P. Wei, The Current Situation and Strategies of China's Soybean Export Trade in the Context of International Soybean Supply and Demand. Practice in Foreign Economic Relations and Trade 9, 45-49 (2019) doi: 10.3969/j.is s n.1003-5559.2019.09.011. 
6. X. Guo, W. Qiu, Q. He, H. Zhang, R. Huang, Q. Zhang, The development and advantage analysis of soybean processing industry in Hubei Province. Experimental study 1, 69-70 (2011)

7. L. Wang, J. Zhou, W. LI, J. Yu, Y. Lai, M. Liu, M. Liu, Effect of New Agents on Heteroderaglycines Control and Yield of Soybean. Soybean Science 36(6), 944-950 (2017)

8. C. Zhang, C. Liu, B. Li, X. Jing, Research Progress on the Effect of Organic Fertilizer on Soybean Production. Anhui Agricultural Science 46(18), 25-28 (2018)

9. M. Cheng, M. Li, Z. Chen, H. Bao, Empirical study on the effect between agricultural mechanization and grain yield in China. Guangdong Agricultural Science 18, 198-201, 219 (2013)

10. W. Kong, Study on the promotion path of soybean international pricing power in China. Price Theory and Practice 7, 66-68 (2017)

11. Y. Sun, M. Qin, International Soybean Futures Prices and Linkage Analysis of Domestic Soybean Futures Prices. Price Theory and Practice 12, 123-126 (2018)

12. H. Wei, China's Resistance of US Soybeans and Its Insight. Frontiers 8, 34-39 (2018)

13. L. Wang, The Influence of Sino-US Trade Friction on China's Soybean Industry. China Grain Economy 10, 54-59 (2018)

14. S. Ma, An Analysis of Market Power of China in Soybean Import Market. (Master), Nanjing Agricultural University https://kns.cnki.net $/ \mathrm{kcms} /$ detail/detail.aspx?dbcode=CMFD\&dbname=CMFD201801\& filename $=1017261507 . n h \& v=$ RMHfy12xHuUqaZCratMeUEbvar0ExFnPki\%25mmd2 F\%25mmd2FCGfkE4GUKHDDCU4CL74dqhJ9IOsN (Last accessed 2021/02/12)

15. J. Liu, The Analysis of Trade Potential of Brazilian Soybean Imports from China Based on Gravity Model. Modern Business Trade Industry 24, 38-40 (2019)

16. T. Guo, Study on Dilemma and Way Out of China's Soybean Production. (PhD), Jilin Agricultural University (2017)

17. J. Wang, Y. Han, H. Lu, The Comparative Study on Soybean Trade in China and Brazil. Modern Management Science 11, 15-17 (2018)

18. S. Zhou, Y. Qian, The comparison of cost-benefit of soybean production in the United States and Brazil and its implications for China. World Agriculture 2, 113-118 (2018)

19. Y. Wang, X. Ji, X. Lian, T. Li, C. Liu, L. Wang, Analysis of China's Soybean Imports Situation and Its Effect. China Post Science and Technology 9, 4-10 (2020)

20. A.N. Spartak, N.N. Yevchenko, The socioeconomic situation in Transdniestria. Studies on Russian Economic Development 27(4), 446-452 (2016)

21. N.N. Yevchenko, Currency transactions and Customs flows in the foreign economic relations of a region (Based on the example of Rostov oblast). Studies on Russian Economic Development 22(4), 410-420 (2011)

22. N. Cui, W. Liu, The impact and countermeasures option of global soybean trade pattern change on China's soybean industry. Soybean Science 38(4), 629-634 (2019)

23. Y. Wang, J. Song, Study on the integration development of ecological agriculture industry chain in Heilongjiang and Far East of Russia. Economic Perspective 8, 133-134 (2020)

24. F. He, Analysis on the construction of international joint laboratory of Chinese and Russian agriculture. Modern Agricultural Science and Technology 5, 255-257 (2020) 